\title{
CASTORIADIS: UMA FILOSOFIA PARA A EDUCAÇÃO
}

\author{
LílIAN DO VALLE*
}

\begin{abstract}
Com efeito, mesmo que haja algo de Único, comum a tudo que chamamos bens, ou algo em separado que seja o Bem em si mesmo, é evidente que não é nem praticável nem acessível ao homem; ora, o bem que buscamos é alguma coisa que esteja a nosso alcance. (Aristóteles, Ética a Nicômaco, I, 1096, b 30-35) ${ }^{1}$

À memória do filósofo que jamais fez o luto de Aristóteles. (Cornelius Castoriadis, 1922-1997)
\end{abstract}

\begin{abstract}
RESUMO: Há muitos tipos de filosofia, muitos estilos de praticá-la e muitas razões pelas quais a convocamos, quando se trata de falar das coisas humanas. No livro I da Ética a Nicômaco, Aristóteles afirma contra o que fora, durante toda a existência, o principal objeto de busca de seu mestre - que a investigação que lhe interessa é aquela que trata do que é acessível e praticável pelos humanos. Ora, esse tipo de filosofia, que me parece ser a única digna da educação, é definitivamente a que praticou Cornelius Castoriadis. Assim, a filosofia foi insistentemente descrita, na obra do autor, como interrogação aberta $e$ incessante, que nada tem de fútil exercício de especulação, na medida em que concerne fundamentalmente à atividade de criação, por parte de cada humano, dos sentidos que fazem existir seu mundo próprio - e que, portanto, concerne igualmente aos sentidos que edificam a vida comum.
\end{abstract}

Palavras-chave: Filosofia da educação. Teoria da educação. Autonomia. Complexidade. Castoriadis.

* Doutora em Educação e professora titular de Filosofia da Educação da Universidade do Estado do Rio de Janeiro (UERJ). E-mail: lvalle@infolink.com.br

Educ. Soc., Campinas, vol. 29, n. 103, p. 493-513, maio/ago. 2008 


\section{CASTORIADIS: PHILOSOPHY FOR EDUCATION}

ABSTRACT: There are many kinds of philosophy, many styles of practicing it, and many reasons fort taking it when it comes to talking about human things. In book I of The Nicomachean Ethics, Aristotle affirms that the inquiry that interests him is what is accessible and practicable to human beings. This kind of philosophy, that seems to be the only one that is worth the field of education, is definitively the one practiced by Cornelius Castoriadis. Thus, philosophy was insistently described, in his works, as open and nonstop questioning that is not considered as useless exercises of speculation, because it basically concerns the activity of creation, by each human being, of the meanings that make his/her own world exist, and is, therefore, equally related to the meanings that build up common life.

Key words: Philosophy of education. Educational theory. Autonomy. Complexity. Castoriadis.

\section{Uma filosofia para a educação}

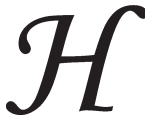

á muitos tipos de filosofia, muitos estilos de praticá-la e muitas razões pelas quais a convocamos, quando se trata de falar das coisas humanas. No livro I da Ética a Nicômaco (2004, 1096, b 30-35), Aristóteles esboça um dos traços fundamentais de seu estilo próprio: a recusa da Verdade autônoma, intangível, imperecível, absoluta, que fora, durante toda a existência, o principal objeto de busca de seu mestre. Não eram poucos nem desprezíveis, entretanto, como ainda não o são hoje, os charmes da Idéia bela e perfeita. De minha parte, no que concerne à educação, duas tentações me parecem temíveis, exatamente pela grande atração que exercem: a de reduzir a filosofia aos belos discursos repletos de palavras poéticas, de frases convenientemente ambíguas, de expressões que aquecem o coração e fazem vagar o pensamento - filosofia-poema que só compromete nossa sensação fugidia e nada acrescenta à busca de sentido; e, pode-se dizer, o seu oposto, o de assimilá-la inteiramente ao hermetismo dos discursos "especializados", sempre enigmáticos para os não-iniciados, discursos que acreditam legitimar-se por e em sua obscuridade, repletos de frases que giram em torno de si mesmas, redundantemente precavidos contra qualquer utilização apócrifa, enfim, contra qualquer uso prático que se possa conferir à teoria - eternamente, filosofia-exegese. 
Sem dúvida, faz parte da experiência do pensamento nos habituar a permanecer sensíveis àquilo que se oferece a nós de imediato, sob forma de beleza, tanto quanto a permanecer atentos àquilo que a nós de imediato se recusa, sob forma de uma sabedoria a que passamos a aspirar. Mas a experiência do pensamento não pode se alimentar apenas desses encontros fortuitos de primeiros momentos, sob o risco de se extinguir ou de se fixar - o que, nesse contexto, diga-se de passagem, é exatamente a mesma coisa.

Afinal, não é raro que o encontro com a beleza inefável ou com o conhecimento perfeito ceda lugar à descoberta, mais rápida ou postergada conforme cada um, de que os "ganhos" que pensávamos haver feito nos escorrem pelos dedos. Assim, eu não hesitaria em adotar para o campo da formação humana a exigência a que se refere Aristóteles, ainda no início da Ética a Nicômaco: a de que o objeto visado pela reflexão possa efetivamente concernir à prática e ao "uso" humanos. Não se trata, é claro, de restringir o campo do pensável ao que já está dado e apropriado em nossa realidade cotidiana, longe de lá: o objeto que nos interessa deve ser buscado, porque em caso contrário não haveria sentido em se recorrer à reflexão; mais ainda, ele deve ser continuamente buscado, na medida em que ele existe em e por esse movimento de busca e não como um saber de que poderíamos nos apropriar definitivamente, de uma vez por todas.

A injunção aristotélica - que para Platão decerto soaria como um a-menos, embora seja extremamente exigente - define, pois, um compromisso pelo qual, ao invés de perder-se na eterna imensidão do céu das idéias ou de curvar-se às seduções passageiras da palavra, o pensamento escolhe submeter-se à medida do humano.

Ir ao encontro do que somos, lá onde estamos, e desse modo nos permitir alterar consciente e deliberadamente nossa prática: inscrita na tradição democrática de que Aristóteles se nutriu, essa filosofia, filosofia encarnada, é definitivamente aquela que praticou Cornelius Castoriadis.

\section{Filosofia para quê?}

Em Feito e a ser feito - texto que é, segundo suas próprias palavras, um "balanço" de seu itinerário intelectual -, Castoriadis (1998, p. 13) definia a filosofia como "compromisso com a totalidade do pensável". Ele não se referia, decerto, à arrogante e ingênua ilusão de tudo pensar, ou 
tudo conhecer, que seduziu e ainda hoje seduz a tantos, mas simplesmente à atitude de levar a sério a convicção que fez nascer a filosofia: a de que tudo o que vivemos e concebemos pode e deve ser objeto de nossa interrogação. Convicção que, por sua vez, no mundo antigo, fora motivada pela crescente consciência de que não há lei natural, determinação histórica ou mandamento divino que estabeleça antecipadamente qual é a totalidade do que é dado ao humano pensar, e onde se situam os limites a partir dos quais essa atividade do pensamento deveria cessar; consciência, enfim, de que não há fatalidade ou condenação que forcem a adesão irrefletida às verdades anunciadas pelos sacerdotes, pelos mais experimentados, pelos responsáveis públicos, pelos especialistas...

Assim, a filosofia foi insistentemente descrita, na obra do autor, como interrogação aberta e incessante, que nada tem de fútil exercício de especulação, na medida em que concerne fundamentalmente à atividade de criação, por parte de cada humano, dos sentidos que fazem existir seu mundo próprio - e que, portanto, concerne igualmente aos sentidos que edificam a vida comum. A filosofia de que nos fala Castoriadis é, portanto, aquela que tem origem na Grécia antiga, não por acaso no contexto da invenção da democracia. Filosofia, pois, antes de qualquer outra coisa, como possibilidade de exame crítico da atividade de instituição das crenças, valores, aspiraçōes, hábitos que definem o modo de ser coletivo e o modo de ser particular de cada um: essa instituição, que em cada sociedade, em todos os tempos, se realiza de forma espontânea e irrefletida, pode agora tornar-se - em vista, justamente, da interrogação - consciente e deliberada. Entende-se assim porque a filosofia está intimamente ligada à democracia: é o horizonte democrático que permite esse questionamento radical de que, por sua vez, se alimenta.

A essa tradição se opõe, desde Platão e até os dias de hoje, aquela que insiste em fazer da filosofia uma função reservada aos experts, encarregados de produzir teorias, ou de fornecer os conceitos com ajuda dos quais se espera que aqueles que têm por dever de ofício permanecer mergulhados na prática deverão esboçar alguma forma derivada (primitiva? Carente?) do pensar. $\mathrm{O}$ que se segue é apenas a decorrência necessária do que foi anteriormente afirmado, mas que a maior parte do tempo se pretende fazer passar despercebido: pois, por essa lógica, torna-se necessário que aquilo que esses últimos, os práticos, pensam esteja antecipado e inteiramente prescrito e delimitado pelo que as "teorias" fixaram... É espantoso relembrar que essa posição corresponde bastante bem ao que se 
denominou, no mundo antigo, de aristocracia: o poder dos aristo $i$, ditos os "melhores", que formam no seio da comunidade um grupo especial, um grupo à parte.

É essa concepção propriamente aristocrática da filosofia, ou mesmo da teoria, de forma mais geral, que o pensamento de Castoriadis permite criticar. As exigências do projeto de autonomia - que, a tempo e a contratempo, ele tem o cuidado de lembrar não poder jamais limitar-se a projeto individual, mas envolver também a dimensão coletiva - se exercem, dessa forma, na própria relação com a teoria. Em outras palavras, o caráter alienante de uma teoria se evidencia facilmente pelo seu conteúdo, mas decerto muito mais arduamente pelo modo como freqüentemente a acolhemos, pela forma como a ela nos apegamos até o ponto de esquecer de recolocá-la em questão (Castoriadis, 1998). A teoria se transforma, assim, em seu oposto: naquilo que, ao invés de convocar, impede a reflexão. Seria, então, o caso de manter à distância o conjunto das teorias instituídas, optando a cada vez pela "autenticidade" das próprias considerações? Deverse-ia voltar a afirmar de forma insistente que todos são naturalmente filósofos? Nada mais afastado do pensamento de Castoriadis do que essa idéia que, no entanto, durante um bom tempo, freqüentou o discurso educacional, nem sempre para sua maior glória ${ }^{2}$ (Valle, 1997). Para Castoriadis, ao contrário, a filosofia é uma atividade que nada tem de espontânea: ela é uma artificialidade - se nos é permitida a expressão -, uma disposição adquirida para a interrogação; mas essa aquisição não se realiza automaticamente, nem de uma vez por todas, ela deve ser incessantemente refeita, de modo que seria excessivo falar aqui, com Rousseau (1995, p. 25-45), por exemplo, de uma segunda natureza. Diga-se, antes, que a filosofia é o exercício de contínua busca e aquisição de uma disposição que se trata, a partir daí, de tentar tornar durável. O requisito é, pois, a aceitação de que é preciso recolocar continuamente em questão as certezas, os hábitos instituídos, as crenças e os valores sob os quais nossa existência e nosso saber, nosso modo de ser e de agir se sustentam. O que em nada implica a demissão da teoria, mas, ao contrário, a supõe eminentemente necessária, ao mesmo tempo em que torna igualmente indispensável o estabelecimento de uma atitude de resistência à submissão e ao conformismo em que as idéias a que muito nos apegamos tendem a nos entreter.

Assim, se filosofamos, se devemos filosofar não é por outra razão além de "(...) salvar nosso pensamento, e nossa coerência", afirma Castoriadis (1998, p. 15). Como, de toda forma, nosso pensamento e nossa 
coerência jamais poderiam ser salvos por outrem, cabe concluir que filosofamos para construir e exercitar nossa autonomia: para interrogar os sentidos que recebemos da tradição, de nossa sociedade, de nossa história pessoal e coletiva... Fazemos filosofia porque não há outro modo de construir coerentemente o sentido cotidiano de nossa prática, senão pelo exame.

Assim definida, está claro que a prática filosófica não poderia jamais se acomodar à "divisão de trabalho" tão exaustivamente denunciada há algumas décadas, e que consiste em separar arbitrariamente a teoria e a prática, para depois buscar de forma igualmente artificiosa estabelecer entre ambas uma "ordenação".

Ao contrário, essa forma de conceber as coisas nos obriga a interrogar o hábito, infelizmente corrente, de se pretender fazer teoria da educação unicamente a partir da prática de outrem - mantendo sob silêncio sua própria prática educativa. $\mathrm{Na}$ medida em que jamais se reconhece como origem de suas interrogações, o teórico não tem como colocar em questão sua própria prática; por isso, faz da teoria o exercício de produzir, de cima e de fora da atividade visada e sempre praticada por outros, os princípios que deverão orientá-la. Há, para esse engodo, muitas figuras emblemáticas: como a do "filósofo" que pretende nada saber de educação, ainda que tenha recebido do ofício de professor os proventos regulares que sustentaram seu "filosofar". Esse "filósofo" que pensa sobre tudo, menos sobre sua própria prática, é como a revivescência contemporânea da antiga e grotesca imagem do filósofo que vive com a cabeça nas nuvens e os pés ali onde não se deve colocá-los, imagem essa que muitos têm por apanágio de grandeza, como se pés sujos correspondessem forçosamente a uma cabeça atenta às coisas que realmente importam... Menos anedótica e mais corrente, a figura do docente-pesquisador universitário, cada vez menos docente, se é que mais pesquisador, adquire, especialmente na área da educação, as feições humanizadas do paradoxo: pois quantos "teóricos" da educação não se transformaram sob nossos olhos em verdadeiros globe-trotters da teoria educacional, vedetes rotineiras dos incontáveis encontros, palestras e conferências que os afastam definitivamente da atenção devida e do compromisso assumido com os simples afazeres de sua profissão de... professores? Mas não é só nas entrelinhas mais sinuosas da carreira universitária que se estampa o caráter estruturante da divisão teoria e prática: ela também se manifesta vigorosa e decididamente nos currículos dos cursos de formação do professor, 
que partem do pressuposto de que não somente é possível, mas desejável fornecer ao noviço, inicialmente, um conjunto pronto de teorias que assegurarão o grosso de sua "formação", e das quais deverá dispor para, posteriormente, "aplicá-las" no ofício de educar.

Referi-me há pouco às críticas já estabelecidas da "divisão de trabalho" educacional, da separação entre teoria e prática: elas evidentemente depõem contra a organização político-organizacional da educação em nossa sociedade, tanto quanto contra a epistemologia que lhe serve de base. Mas a crítica sociológica e epistemológica permanecerá superficial, se não recuar alguns passos para se fazer questionamento dos pressupostos ontológicos que sustentam nossa concepção e nossa prática. É nesse sentido, radical, que a filosofia de Castoriadis pode, a meu ver, prestar uma das maiores contribuições à área da Educação: simplesmente recolocando em movimento questóes que há muito parecem ter sido esquecidas, mas que estão na origem de qualquer gesto, disposição ou deliberação sobre a educação. São elas, por exemplo: "Quem é esse ser (sempre encarnado e particular) que tenho diante de mim, e o que ele me revela sobre o modo de ser (racional, mas também estético e afetivo) desse que eu chamo correntemente de aluno?"; mas também: "O que é, de onde veio e para onde vai essa sociedade que tenho diante de mim, e o que isso me revela sobre o que posso e desejo chamar de educação, professor, aluno?" (e aí, por exemplo: Até onde, em nossa experiência formativa contemporânea, a idéia de natureza humana foi criticada, ou permanece intacta, justificando algumas das ações correntemente adotadas?).

Falar de compromisso com a totalidade do pensável é, pois, antes de tudo, falar de compromisso em pensar a própria realidade, sem reservar escrupulosamente para os "especialistas" a tarefa de construir os sentidos necessários para movimentar o mundo e a prática dos professores. É a instauração desse questionamento radical que obriga a entender a filosofia... como uma ontologia.

E eis que pronunciei a palavra proibida e conjurei uma prática mil vezes sob suspeita: quem ousaria, nos dias de hoje, falar em ontologia, tantos foram os preconceitos sobre ela lançados pela (má) recepção das teorias da "morte do sujeito"? (Castoriadis, 1992a, p. 201). Como resposta e desagravo - não da ontologia, mas de nossa liberdade de interrogação -, talvez fosse o caso de indagar o que as teorias que afirmam que nada pode ser formulado sobre o sujeito têm efetivamente a oferecer para a prática de educação e, mais ainda, para a educação democrática. No entanto, e no 
simples intuito de não fechar a discussão antes mesmo de começá-la, é preciso convir que as teorias que afirmam que nada pode ser afirmado sobre o humano, uma vez que tudo é fluxo, que o ser é perpétuo devir, e toda impressão de estabilidade apenas uma ilusão, não fazem outra coisa além de erigir... uma ontologia, uma teoria sobre o vivente.

Seja, portanto, a ontologia como possibilidade de se interrogar sobre a própria existência e sobre seus sentidos, sabendo-se de antemão que só o que poderemos conhecer é o que delas faz nossa reflexão.

Dizemos: há uma reflexão/elucidação que se preocupa com o ser/ente e se pergunta sobre o que lhe pertence de próprio e o que lhe pertence na medida em que ele é para nós - isto é, pelo fato de sobre ele refletimos. Esta formulação afirma que é impossível separar reflexão sobre o ser e reflexão sobre os entes, como é impossível separar reflexão sobre o ser e "teoria do conhecimento". (Castoriadis, 1998, p. 16)

Logo, longe de se tratar da afirmação de uma "verdade" absoluta e intemporal acerca da condição humana, a ontologia refere-se aqui ao compromisso de parar simplesmente de ignorar o humano e as especificidades a partir das quais, a cada vez, ele se apresenta a nós; parar de ignorar que, humanos, temos questões, e sérias questões, acerca do que somos e do que são os que nos rodeiam - ao invés de persistir supondo que o que fazemos, ao pensar na vida, não tem qualquer espécie de relação com o que reputamos serem as mais altas elucubrações teóricas. Ontologia é, portanto, a afirmação de que há certo conhecimento que se faz indagação relativa ao que cada ser tem de próprio - para uns, o devir; para Castoriadis, o poder de criação - que, mais do que de anomalias irredutivelmente singulares, pode ser a origem de um projeto comum. No entanto, Castoriadis era o primeiro a advertir:

Uma pesquisa ontológica que se oriente para a idéia de criação dá lugar, da maneira mais abstrata, tanto à possibilidade de instauração de uma sociedade autônoma, quanto à realidade do stalinismo e do nazismo. Assim, neste nível, e em quase todos os outros, criação não possui nenhum conteúdo de valor, e a política não se deixa "deduzir" da ontologia. (Idem, ibid.)

$\mathrm{Na}$ medida, porém, em que é impossível separar reflexão sobre o ser e teoria do conhecimento, ontologia quer dizer interrogar também as teorias de que lançamos mão para pensar os seres em suas diferenças. 
Aqui, de novo, a reflexão de Castoriadis nos permite ferir um novo engodo, que, quanto a esse, se apresenta sob a forma da estrita incorporação de conceitos e teorias advindas das ciências físicas ao estudo dos fenômenos humanos. Nesse sentido, o relativo sucesso das "teorias da complexidade", que lançam mão do aparato metodológico de explicação do mundo físico construído pela biologia, só pode aparecer como uma triste "recaída" em relação a um ideal de cientificidade que acreditávamos inteiramente ultrapassado.

Ontologia significa o que tradicionalmente se denominava metafísica (...). Sabemos que a palavra é um acidente histórico. Não obstante, é no livro intitulado por outros, e posteriormente, Meta ta phusika, que Aristóteles audaciosamente afirmou: há uma certa ciência (epistémé) que considera o ser/ente (on) como: ser/ente e aquilo que lhe pertence a-si-mesmo (verssoi, kat'auto, em si mesmo). (Idem, ibid.)

Meta ta phusika é "o que vem depois" do tratado denominado Fisica, e que investiga, ao que parece pela primeira vez, a existência por ela mesma, e não em relação a uma idéia de deus ou da natureza.

Se me for permitido dizer algo que, a meu ver, não é apenas um gracejo, eu diria que chegou a hora, talvez, de inverter o procedimento tradicional. Em vez de tentar descobrir em que medida é possível explicar o que sucede ao homem por meio da física e da biologia e, por exemplo, prosseguir supondo que uma idéia, um mito, um sonho não são mais do que resultados epifenomenais de um certo estado do sistema nervoso que seria, por sua vez, redutível a, digamos, um certo arranjo de elétrons, poderíamos talvez tentar, com finalidades heurísticas, inverter o procedimento. Todos se recordam que, quase sempre, os filósofos começam dizendo: "Quero saber o que é o Ser, o que é a realidade. Ora, eis aqui uma mesa; o que é que essa mesa me exibe como traços característicos de um ser real?". Jamais qualquer filósofo começou dizendo: "Quero saber o que é o Ser, o que é a realidade. Ora, eis aqui minha lembrança de meu sonho da noite passada; o que é que ela me exibe como traços característicos de um ser real?”. (Castoriadis, 1987, p. 227)

A apropriação indiscriminada de metáforas, conceitos e categorias provenientes das ciências naturais ou matemáticas - da teoria dos conjuntos, das teorias do caos, dos fractais, das análises topológicas etc. resulta, sem qualquer dúvida, da constatação dos impasses a que chegaram os esquemas teóricos e conceitos que pretendiam desvendar e explicar inteiramente a realidade humana e social. Mas, deixando de lado o 
que muitas vezes se deveu tão somente à extrema fragilidade das bases sobre as quais o pensamento da Educação se erigiu, resta, ainda aqui, que o caráter provisório e incompleto do conhecimento sobre o humano não é apenas uma questão epistemológica, mas propriamente ontológica: ela não fala apenas sobre os limites de nosso conhecimento, mas também do pouco que podemos dizer acerca do modo de ser próprio desse objeto que buscamos conhecer.

Digamo-lo, de uma vez: o humano (que somos) se apresenta a nós como complexo e enigmático. Essa constatação deveria nos conduzir a redobrar a vigilância em face dos métodos, dos procedimentos, dos critérios que utilizamos para organizar o que, no humano, é organizável, para formalizar (isto é, submeter à forma-teoria) o que, no humano, é passível, ainda que fracionária e provisoriamente, de formalização. No entanto, é todo o contrário que se dá: na ausência de uma reflexão mais aprofundada, a idéia de complexidade tem servido de argumento para a relativização das exigências e peculiaridades da reflexão sobre o homem.

Pelo menos desde a década de $1970^{4}$ a reflexão ontológica de Castoriadis já permite compreender que, ao se falar de complexidade, é preciso discernir pelo menos entre duas condiçôes. A primeira dessas condiçôes o humano compartilha com todos os entes naturais. Assim, o que os estudos dos fenômenos naturais, puramente físicos, colocam em evidência e que, sem dúvida, pode ser transposto para a compreensão do estrato biológico-natural de nossa existência são os limites de uma lógica que, no entanto, está amplamente presente em nosso cotidiano. Os pressupostos dessa forma de organizar a realidade (que são, eles próprios, de natureza lógicoontológica) foram consignados por Aristóteles, nos princípios de identidade, não-contradição, terceiro excluído; de equivalência entre propriedade e classe (possibilidade de operação classificatória); de relaçóes de equivalência e de ordenação; todos esses contidos, enfim, na noção de que é possível, identificando as determinaçóes que pesam sobre os seres, explicá-los inteiramente - princípio que Castoriadis (1987, p. 398; 1992, p. 401) denomina de "determinidade". Com base nessa lógica, que o autor apelida de "conjuntista-identitária" e que tem na teoria dos conjuntos sua versão matemática, trabalha a ciência. Mas não só ela! A partir dela também operamos, inevitavelmente, cada um de nós, em nossas mais simples atividades cotidianas - e inclusive, também, de forma mais marginal, em nossos sonhos, na literatura, na simbolização, no mito: de outro modo, como poderíamos sequer falar dessas experiências e de seus produtos? 
Assim, se é verdade que os operadores em que a "lógica tradicional" se apóia não são suficientes para pensar todos os aspectos da realidade natural, também é certo que eles, longe de poderem ser ultrapassados, têm uma inegável efetividade no domínio da existência, correspondendo a, pelo menos, uma dimensão do ser: “(...) a lógica conjuntista-identitária repete, prolonga, elabora (...) uma parte essencial da lógica do vivente. Sem dúvida, em uma imensa parte de suas operações (...) o vivente opera por meio de classes, propriedades e relações" (1992a, p. 415).

Contudo, face à complexidade, e para além da lógica conjuntistaidentitária (em sua forma matemática ou, por exemplo, em suas formulações topológicas), Castoriadis (1987, p. 416) afirma que "o que existe não é conjunto nem sistema de conjuntos”, nunca é plenamente determinado, ou exaustivamente determinável. Mas não sem lembrar, igualmente, que tampouco o que existe é puro caos, fluxo ininterrupto, insensato e incontrolável. Pois a realidade comporta uma dimensão conjuntista-identitária "ubiquamente densa" (ibid., p. 414). À necessidade/capacidade humana de organizar minimamente sua experiência, construindo um mundo como sentido - e não como puro caos -, corresponde esse "estrato" da realidade que se presta à organização conjuntista-identitária - e isso vale para uma ampla dimensão da existência dos homens e das sociedades.

Uma pequena digressão talvez não seja inútil no contexto da reflexão educacional: ela se deve à necessidade de verificar até que ponto essa lógica, que o epíteto de "aristotélica" parece cobrir de opróbrio, pode ser de fato definitivamente "superada".

Ora, não se acabou de afirmar, com Castoriadis, que "é impossível separar reflexão sobre o ser e a teoria do conhecimento" que sustenta esta reflexão? Se, “(...) para o observador, a questão de saber, num sentido último, o que provém de si mesmo e o que provém do observado é indecidível (...)" (ibid., p. 416), não deveríamos reconhecer que tudo é subjetividade, que vivemos mergulhados na impossibilidade de não só romper com os sentidos que nossa subjetividade nos apresenta (que são nossos, mas desde quando e a partir do que?), mas igualmente de compartilhar de sentidos que nos são apresentados?

Se não somos forçados a proclamar que todos os saberes (não importa quais e em vista do que) se equivalem - e, portanto, a anunciar a futilidade de nossas reflexões e do próprio desafio da educação - é porque 
podemos, mediante um esforço deliberado e coletivamente aceito, submeter o que para nós se constitui em sentido ao exame de suas condições e limites de validade. A "superação da lógica tradicional" não é, pois, recusa das exigências que o pensamento se dá a si próprio, na intenção de ir mais longe: é o caminho árduo que é preciso empreender para não escravizá-lo aos sentidos mais imediatos, mais redutores e mistificados que a realidade pode ter para nós (Valle, 2003, p. 185-201).

Mas a questão não se esgota aí. Há ainda uma segunda condição de complexidade - esta, decididamente, humana - que, quanto a ela, não se deixa apreender pelos esquemas de determinidade, pela lógica conjuntista-identitária, mas se constitui no que Castoriadis denominava a dimensão prático-poiética, ${ }^{5}$ a dimensão propriamente criadora, imaginária do humano.

Com crescente clareza, Castoriadis admite que a phantasia, a capacidade de criação não é monopolizada pelo humano. Ao contrário, todo vivente cria os sentidos de seu "mundo próprio" - a mera sobrevivência exige até mesmo de um vírus a capacidade de poder significar diferentemente o que ele próprio é, e o resto; e, entre tudo o que lhe é estrangeiro, o que se constitui em ameaça para sua existência e o que, ao contrário, contribui para perpetuá-la. No vivente em geral, diz-nos Castoriadis, essa criação de sentido é quase inteiramente determinada pela funcionalidade - pelo que habitualmente chamamos, justamente, de "instinto" de conservação e de reprodução. No humano, entretanto, o poder de criação é quase que inteiramente liberado dessa determinação "natural" que ele compartilha com todos os viventes, e assim este poder dá origem ao magma das significaçôes que compóem sua existência individual e coletiva (Castoriadis, 1992a, p. 416). Essas criações não se deixam reduzir às "explicações" que para elas se produziram e que dizem respeito a causas físicas, lógicas, históricas, sobrenaturais que determinariam seu aparecimento... Complexas, porque é impossível controlar ou descrever inteiramente as causas de sua emergência, elas não dão, entretanto, lugar aos graus de incerteza e de indeterminação da realidade física, mas despontam, muito pelo contrário, como novas "certezas" e "determinações" (idem, ibid.).

É essa a grande diferença, a diferença fundamental que a interrogação sobre o homem - rigorosamente falando, que a aceitação do humano como paradigma para a existência - introduz: na dinâmica do conhecimento exato, o que escapa à determinação revela os limites 
intransponíveis do entendimento. No entanto, na dinâmica que a existência humana deixa perceber, o que escapa à determinação aponta para as possibilidades inesgotáveis de criação, individual e coletiva:

A não determinação do que existe não é simples "indeterminação" no sentido privativo e, em última análise, trivial. Ela é criação, a saber, emergência de determinaçôes diferentes, de novas leis e de novos domínios que se submetem a elas. A "indeterminação" (na medida em que ela não é entendida apenas um "estado de nossa ignorância", ou uma condição "estatística") tem esse sentido preciso: nenhum estado do ser pode ser tal que venha a tornar impossível a emergência de determinações diferentes das que já existem. (Idem, 1998, p. 417)

Eis, pois, o que "minhas lembranças de meu sonho de ontem à noite", como queria Castoriadis, me descortinam: para além da lógica conjuntista-identitária que ali não deixa de estar presente (eu tenho medo, e corro; a chuva me molha; alguma coisa cai e se quebra), há um enorme fluxo de sentidos que escapam não só às minhas lembranças, mas, em minhas lembranças, a todas as fórmulas que conheço para pensá-las e reproduzi-las. Paradigma radical da criação, em meu sonho eu sou, estranhamente, eu e o oposto de mim; há, no modo de ser de nosso sonho, como assinala Castoriadis (1987), uma subdeterminação e uma sobredeterminação dos significantes, paralela a uma subsimbolização e a uma sobresimbolização das significações etc. Excessivos $e$ carentes, os elementos da linguagem e da representação estão longe de manter entre si uma relação direta e unívoca; eles nunca esgotam os sentidos do que é sentido para o humano. Há sempre esse resto, um resíduo, e então há, no que foi dito, um "a mais" que não corresponde a nada; como há algo de indizível, que nos escapa a nós mesmos. Nada aqui faz pensar na teoria cantoriana dos conjuntos, com seus elementos claros e discerníveis de atributos definíveis, que mantêm relações definíveis, ainda que múltiplas e em múltiplas direções, com outros elementos, subconjuntos e conjuntos. O que se passa então - como a psicanálise, que também começou pelo sonho, pôde verificar - permite finalmente entender que, no que se refere à existência humana, não há "ciência" que permita explicar ou formalizar essa criação ininterrupta de sentidos, não há ciência do sentido, isso é, não há saber capaz de me revelar inteiramente o que se passa em meu próprio sonho. E, se esse sonho não é inteiramente determinado por alguma força oculta exterior a mim, devo entender que essa criação é minha imaginação radical. 
Psicanalista, Castoriadis faz do sonho o modelo para pensar a existência e a especificidade humanas, para elucidar a imaginação radical do humano - para quem, diferentemente dos animais e das coisas, a autonomia não é fechamento em um sentido originário (psíquico ou sóciohistórico), mas, muito pelo contrário, a própria possibilidade de questionamento desses sentidos instituídos e de instituição de novos sentidos; seja, pois, o sonho como paradigma para pensar a existência desses entes, em particular: o humano, a sociedade - para os quais a indeterminação não é o caos, mas a possibilidade de criação de novas determinações.

\section{O que "teoria” pode também querer dizer}

Em um texto escrito em 1968, Castoriadis (1987) analisa o contexto em que o ideal de um saber seguro se edifica. A Antigüidade, como sabemos, havia já formulado o princípio de um saber estável que, escapando à maldição lançada por Górgias, pudesse ser objeto de comunicação e de demonstração rigorosa. ${ }^{6}$ Em outras palavras, as condições epistemológicas colocadas para o saber eram, ao mesmo tempo, as condições que permitiam sua socialização. No Ocidente, esse projeto tornou-se realidade correntemente instituída com o advento da ciência moderna, que se estabelece definindo-se como produção e reprodução dos fenômenos na experimentação e na observação, como "(...) inferência formalizável (ainda que parcialmente) dos enunciados, como correspondência unívoca de uns e outros; ela constitui seus resultados como verificáveis e acessíveis a todos os que quiserem dar-se ao trabalho de estudá-los" (Castoriadis, 1987, p. 41).

A estrita formalização que permite que os resultados possam ser rigorosamente comunicados nada mais é, como assinala Castoriadis, do que a instalação de procedimentos públicos de verificação e de falsificação, a partir dos quais se torna possível uma verdadeira divisão de tarefas; dessa última, por sua vez, decorre a possibilidade de constituição de uma produção e de uma acumulação social de conhecimentos. Desse modo,

(...) além de permitir um alargamento ilimitado da base humana da ciência, essa invenção tornou também possíveis a aplicação racional da divisão do trabalho e a entrada em um processo de acumulação, não de verdades, mas de resultados e conhecimentos efetivos. Um imenso corpo 
anônimo, socializado, organizado pelo seu próprio objeto, trabalha apoiado sobre uma imensa massa de resultados, cuja acessibilidade universal não encontra nenhum entrave, além de sua monstruosa proliferação: e as mais explosivas revoluçōes nessa massa pressupōem a sua continuidade e não existiriam sem ela. (Idem, ibid., p. 48)

As bases para esta organização são duas, a primeira sendo a eliminação, ou a purificaçãa do conhecimento de tudo o que comporte a subjetividade de uma experiência intransferível e singular e, portanto, intraduzível em termos formais. Contudo, em segundo lugar, o estabelecimento dessa cooperação depende da possibilidade de se tomar, do objeto de estudo, apenas um de seus aspectos, de maneira a que se possa falar de uma verdadeira especialização. Ora, quando se tem o humano como objeto de estudo, essas duas condições são simplesmente irrealizáveis. Nesse domínio, "purificar” o objeto, ou dividi-lo, é o mesmo que matá-lo: “(...) é porque este objeto é sentido encarnado, significação materializada - logoi enuloi, mesmo mais: logoi embioi, significações vivas" (idem, 1987, p. 38).

Como pondera Castoriadis, se, no caso dos fenômenos naturais, a fixação de leis e regularidades, a formalização é o centro de uma atividade cuja periferia é o inexorável reconhecimento da subjetividade e da incerteza que nos cercam, no caso do humano o que estava na periferia se torna o próprio cerne da atividade (idem, p. 37). O humano é significação encarnada: ele existe por suas significaçóes próprias, que em larga medida são fornecidas pela sociedade. Mas o modo de relação dessas significações entre si, e com esse todo que é o humano, não encontra, em parte alguma, modelo.

Como é possível, então, que as atividades que visam o humano em sua condição própria e singular, e não como um vivente entre tantos (a dimensão física de sua existência), possam reivindicar a autoridade $c i$ entifica?

Essa teoria pretendia ser científica; como, com efeito, poderia ser ela outra coisa? O seu objeto é real: essa parte, esse segmento do mundo formado pelos atos dos homens e por aquilo que, neles, esses atos pressupóem (até e inclusive a organização material à qual correspondem). Mas esse princípio aparece, imediatamente, como vazio: esse objeto real, perceptível aqui e agora, difere radicalmente de qualquer outro real, porque o seu momento específico, que o constitui como ordem própria de realidade, é que ele é sentido, sentido encarnado, sentido a cada vez singular. $\mathrm{E}$ não há ciência do sentido: não há formalização possível do saber que trata 
do sentido. Toda formalização pressupõe, ao contrário, que o domínio considerado foi cuidadosamente depurado de todo sentido que podia conter. O fato de que esta depuração nunca possa ser exaustiva, que ela só consista em relegar o sentido ao ponto de origem e ali comprimi-lo, sob a forma de noçōes indefiníveis e de enunciados axiomáticos, é certo e apenas confirma, no mais alto nível, o que é aqui proposto. (Idem, ibid., p. 52-53)

Especialmente no que respeita às atividades que visam o processo de auto-alteração, de formação, às atividades que têm por fim a autonomia humana - e Castoriadis, após Kant (1993) e Freud (1998), ${ }^{7}$ as no-

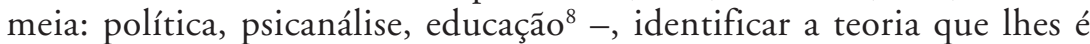
própria a uma ciência é um contra-senso. Afinal de contas, a autonomia implica exatamente isso: o fato de que o que são o humano e a sociedade não se encontra inscrito em uma natureza cujas leis e regularidades, de antemão fixadas, podem assim ser previamente conhecidas, mas depende, a cada vez, de uma criação individual e social arbitrária, que pode e deve ser submetida a questionamento.

O pensamento herdado, dizia Castoriadis, insistiu continuamente em fundar em ciência aquilo que é fruto da criação humana: dispôs-se, assim, a conhecer objetivamente a "natureza" da sociedade, assim como se dispôs a fornecer para a educação novas bases "científicas". Todavia, se há autonomia humana é exatamente porque é impossível reduzir a política e a educação ao conjunto de "explicações" que sobre elas fornecemos, mesmo a posteriori. A autonomia implica, assim, que um grau de imponderabilidade essencial e ineliminável caracteriza a cada vez a política, a educação e a psicanálise, de tal modo que tentar extirpá-lo é, de imediato, descaracterizar essas atividades e cair na pura mistificação. Por isso mesmo, antes de se definirem como objetos de um saber que se pretende especializado, política, educação e psicanálise são atividades que envolvem o poder instituinte da ação humana: poder que pode ser exercido de forma refletida e deliberada, ou não. Comprometidas com o projeto democrático, política, educação e psicanálise têm por fim a autonomia, isto é, uma atividade efetiva de auto-alteração dos indivíduos e sociedades. É esta atividade efetiva que enseja o sentido e, mesmo, a exigência de reflexão e de construção teórica - e não ao contrário, como por vezes pode parecer. Por isso mesmo, não parece de todo ocioso relembrar, como Castoriadis (1987, p. 40) o fazia a respeito da psicanálise, que é a prática que "(...) torna possível a existência de um objeto de saber específico", 
tanto quanto o desejo que passa a visar esse saber. A conseqüência para a definição da teoria própria ao humano é radical:

Assim corno não procede do desejo de saber do analista, a atividade analítica não consiste na aplicação desse saber. Não é somente que o conhecimento da teoria não basta para ser analista; é que a maneira como ela intervém no processo analítico não encontra, em lugar algum, modelo ou equivalente; e nenhuma fórmula simples permite definir a sua função. Pode-se abordá-la dizendo que o analista tem, principalmente, necessidade do seu saber para não lançar mão dele, ou melhor, para saber o que não deve ser feito, para atribuir-lhe o papel do demônio de Sócrates: a injunção negativa. Como nas equações diferenciais, nenhum método geral permite, nesse caso, achar a solução, que é preciso descobrir a cada vez (sem nem mesmo haver garantia de que a solução exista). A teoria orienta, define classes infinitas de possíveis e de impossíveis, mas não pode predizer nem produzir a solução. (Castoriadis, 1987, p. 41)

É esse, segundo Castoriadis, o tipo de teoria que corresponde à educação. Mas a definição da educação como atividade não nos mergulharia, mais uma vez, na antiga aporia relativa às suas finalidades? Ou estaria esse dilema propriamente moderno, que outrora tomou a forma da contradição entre formar e instruir, inteiramente superado? De novo, aqui, é preciso desconfiar das aparências. Afinal de contas, apesar do que possa ser afirmado, é sempre em função de um produto objetivável que a educação pode ser correntemente avaliada pelas políticas oficiais: o que significa que os diversos exames que, do início ao fim das trajetórias de formação instituídas, buscam balizar e qualificar as competências evidenciadas exprimem também uma rigorosa definição dos limites, dentro dos quais se pode exercer a crítica da ação educativa instituída. Por outro lado, a chamada "opinião pública" desenvolve outros parâmetros de avaliação: de forma muito mais direta, ela denuncia a crise atual da socialização dos indivíduos como falência indiscriminada dos modelos educacionais instituídos. A questão, que nada tem de banal, é de plena atualidade: ela diz respeito, por exemplo, à maior ou menor facilidade com que se aceita a idéia de que a "educação a distância” possa se apresentar como panacéia para os problemas educacionais. O que, então, nos servirá de base para pensar a educação, para construir nossas exigências e projetos? O que Castoriadis propõe aqui é a radical superação da idéia de formação como mero desenvolvimento de potencialidades naturais - ou sua desvirtuação, como mais, também, que uma simples busca de "resultados objetiváveis": 
A análise não tem por finalidade a energeia (a atividade) analítica, nem tampouco um ergon (uma obra) exterior ao agente. O ergon da análise como o da pedagogia ou da política - é uma energeia inexistente anteriormente, e esse ergon é daqueles "que a natureza está na impossibilidade de realizar". Não simples atualização das faculdades do indivíduo, atualização de uma potência que preexistiria em ato, mas atualização de uma potência de segundo grau, de um poder poder ser, a análise, como autotransformação, é uma atividade prático-poiética. (Idem, ibid., p. 43)

Isso significa que, para a educação, como para a psicanálise e para a política, atividade e obra, processo e resultado simplesmente não podem ser desvinculados. No humano, a autonomia é o fim buscado, mas também o exercício continuado da interrogação.

$\mathrm{Na}$ obra de Castoriadis, a reflexão sobre a educação concentra-se quase totalmente ${ }^{9}$ nas duas extremidades que definem a auto-alteração: a aprendizagem - que, entendida como categoria biológica, demarca no fenômeno mais amplo da adaptação animal o lugar do humano (1998, p. 40-42) - e a paidéia, o processo de formação desse ser que é, em toda a natureza, o único a quem é dada a possibilidade de autonomia. No primeiro caso, o interesse de Castoriadis pela aprendizagem obedece às exigências da elaboração de sua ontologia - que, para ele, reinserindo o humano na comunidade dos viventes, reserva as marcas da excepcionalidade; no outro, a paidéia é sempre tematizada em sua íntima relação com a política e a psicanálise - o que, sem dúvida, permite elucidar o caráter político da educação, tanto quanto sua responsabilidade na criação de subjetividades reflexivas e deliberantes.

O súbito falecimento do filósofo interrompeu um projeto de consagrar à formação humana uma reflexão mais exclusiva. Entretanto, como essas linhas tiveram a intenção de demonstrar a contribuição de Castoriadis à educação, vai muito além do que aquilo que o autor teve a ocasião de formular explicitamente sobre o tema; e, assim, talvez a melhor definição da filosofia que ele praticou e a maior homenagem que se possa fazer à sua obra sejam propiciadas pelo amplo horizonte de interrogações que seu pensamento a cada vez descortina diante de nós, obrigando-nos a reconhecer que não é aí que se extingue, mas exatamente onde começa o trabalho de nosso próprio pensamento.

Um filósofo - ao que é que se destina? Perguntava-me eu, há dez anos, quando da morte de Castoriadis. A manter interminavelmente aberta 


\title{
a interrogação sobre a autonomia humana - foi, sem dúvida, a resposta que legou àqueles que recorrem ainda hoje a seu pensamento.
}

\author{
Recebido em agosto de 2007 e aprovado em abril de 2008.
}

\section{Notas}

1. A partir da tradução de Richard Bodeüs (Aristóteles, 2004).

2. Na verdade, tal como circulou no meio da Educação, a noção da filosofia como disposição natural de cada um se origina, é claro, de uma definição outra do que é Filosofia, formulada, como se sabe, por Gramsci, mas que em nenhum momento autoriza os excessos cometidos em seu nome (cf., a esse respeito, Valle, 1997, p. 52).

3. O título da "metafísica" é devido aos editores da obra de Aristóteles, e posterior ao filósofo: significaria, em vista de um simples esforço de organização do conjunto de textos, a reunião daquilo que foi por eles disposto após as investigaçôes consagradas à natureza (phusis) (Aubenque, 2002, p. 28). A nova denominação se faz necessária justamente porque o conjunto dos livros da metafísica aparece como dificilmente classificável: não se identificando à "ciência objetiva" da natureza, também não podia ser alinhado ao conjunto de reflexões teológicas. Como se tratava "de uma investigação que não cabia nas divisōes tradicionais da filosofia (lógica, física, moral), nem se enquadrava na estruturação aristotélica do saber (matemáticas, física, teologia)”, “(...) dessa ciência sem nome e sem lugar, em que não reconheciam a teologia, sem, no entanto, poder admitir que fosse outra coisa senão teológica, eles [os editores] fizeram, por séculos, a metafísica." (Aubenque, 2002, p. 28 e 43).

4. Para não mencionar senão alguns registros: o texto "Epilegômenos a uma teoria da alma que se pôde apresentar como ciência", publicado no primeiro volume das Encruzilhadas do labirinto, na França, em 1978, data de dez anos antes, isto é, de 1968; "Ciência moderna e interrogação filosófica" e "Psicanálise, projeto e elucidação", que também integram esse volume, datam, respectivamente, de 1972 e 1977; "A descoberta da imaginação", que compõe o segundo volume das Encruzilhadas, denominado Domínios do homem, é de 1978 (todos os livros editados pela Seuil).

5. Analisando as atividades humanas, Aristóteles as classificou em dois tipos: aquelas que têm fim em si mesmas, isto é, cujo exercício é, por si só, o fim desejado; e aquelas que são meios para a realização de outros fins, que lhes são exteriores. As primeiras, que implicam a realização dos fins da existência, definem a praxis humana por excelência; as segundas, que são atividades de produção de meios para a realização dos fins, definem a poiesis. Para Aristóteles, está claro que a política é praxis, tanto quanto a atividade teórica. Castoriadis objeta que as atividades que visam à formação humana (individual e coletiva) são, de fato, fins em si mesmas, mas guardam também um compromisso com uma efetividade objetiva, e assim os frutos da atividade também devem ser considerados. A impossibilidade de discernir estas duas dimensões é, pois, o que caracteriza as atividades voltadas para a criação da prática, mas também das condições e modos de autonomia humana: política, educação e psicanálise são, indissociavelmente, atividades ditas prático-poiéticas.

6. À musa de Parmênides, que aconselhava a trilhar o caminho da certeza, da verdade perfeitamente cognoscível e estável, e a evitar tudo que não pode ser inteiramente determinado - tirando, assim, da noção de que só pode ser pensado o que existe perfeitamente, essa conseqüência: de que só existe realmente o que o pensamento consegue definir inteiramente

Educ. Soc., Campinas, vol. 29, n. 103, p. 493-513, maio/ago. 2008

Disponível em <http://www.cedes.unicamp.br> 
(Parmênides, 1964, p. 92-98) - Górgias responde com uma provocação: não existiria esse Ser que se deixa apreender e comunicar porque é inteiramente determinado; e, assim, não haveria nenhum caminho seguro, que conduzisse à única certeza da Verdade, simplesmente porque não haveria nenhuma Verdade única e imutável a conhecer: "Nada é, se é, é incognoscível, se é cognoscível é incomunicável (Górgias, 1991, p. 701-705). Quem assim falou sabia, entretanto, que falando fazia existir, ao menos, suas palavras. A verdade as verdades - são, diz o sofista, um efeito do falar (Cassin, 1990, p. 35). E, no idioma grego, há de fato duas maneiras de se valorizar o logos: como pensamento em adequação a uma Verdade absoluta, ou como discurso que faz emergir o sentido, o consenso, a verdade provisória e instável sobre a qual as relações humanas se estabelecem precariamente.

7. Consta das notas de aulas que Kant proferiu, organizadas e editadas por um discípulo, Rink, a célebre citação, segundo a qual "(...) duas descobertas humanas que se deve considerar como as mais difíceis: a arte de governar os homens e a de educá-los” (Kant, 1993, p. 78). A Freud se deve, é claro, o acréscimo da psicanálise: "Quase parece como se a análise fosse a terceira daquelas profissões "impossíveis" quanto às quais de antemão se pode estar seguro de chegar a resultados insatisfatórios. As outras duas, conhecidas há muito mais tempo, são a educação e o governo" (Freud, 1998, p. 247). Segundo Castoriadis, a idéia havia sido expressa em uma recensão que prefacia o livro de Aichhorn, Verwahrloste Jugend, onde é apresentada como um dito espirituoso tradicional, o que não é verdade, mas, cogita Castoriadis, uma maneira espirituosa de fazer passar uma idéia por dito tradicional (cf. Castoriadis, 1992b, p. 152).

8. É claro que a referência perde parte de seu sentido - mas apenas isso - quando se trata da história dessas atividades.

9. Entre as raras exceçôes, três páginas dedicadas à "Educação, cultura, valores", em um artigo intitulado A crise das sociedades ocidentais, em Encruzilhadas do labirinto IV (2002, p. 18-20). Há ainda uma entrevista que, sob o título de "Psiquê e educação", foi publicada nas obras que a família, após a morte do filósofo, tomou a iniciativa de organizar a partir de suas notas de trabalho (2004, p. 197-220). Observe-se, porém, que o conteúdo da entrevista não corresponde às promessas contidas no título e a discussão toma rumos totalmente diferentes daqueles prometidos pelo título.

\title{
Referências
}

\author{
ARISTÓTELES. Ética a Nicômaco. Trad. de Richard Bodeüs. Paris: \\ Flammarion, 2004.
}

AUBENQUE, P. Le problème de l'être chez Aristote. 4. ed. Paris: PUF, 2002.

CASSIN, B. Ensaios sofísticos. São Paulo: Siciliano, 1990.

CASTORIADIS, C. Encruzilhadas do labirinto. Rio de Janeiro: Paz \& Terra, 1987.

\section{CASTORIADIS, C. Encruzilhadas do labirinto II: os domínios do ho- mem. Rio de Janeiro: Paz \& Terra, 1992a.}


CASTORIADIS, C. Encruzilhadas do labirinto III: o mundo fragmentando. Rio de Janeiro: Paz \& Terra, 1992b.

CASTORIADIS, C. Encruzilhadas do labirinto $V$ : feito e a ser feito. Rio de Janeiro: Paz \& Terra; DP\&A, 1998.

CASTORIADIS, C. Encruzilhadas do labirinto IV: a ascensão da insignificância. Rio de Janeiro: Paz \& Terra, 2002.

CASTORIADIS, C. Encruzilhadas do labirinto VI: figuras do pensável. Rio de Janeiro: Paz \& Terra, 2004.

DUMONT, J.-P. (Ed.). Les écoles présocratiques. Paris: Gallimard, 1991. p. 701-705.

FREUD, S. Análise terminável e interminável. In: SAlomão, J. (Org.). Edição Standard brasileira de obras completas de Sigmund Freud. Rio de Janeiro: Imago, 1998. v. 23.

GÓRGIAS. Sobre o não-ser ou sobre a natureza. In: Dumont, J.-P. (Ed.). Les écoles présocratiques. Paris: Gallimard, 1991. p. 701-705.

KANT, I. Réflexions sur l'éducation. Paris: Vrin, 1993.

PARMÊNIDES. Peri phusis, frag. 4-5. In : VoIlquin, J. (Trad.). Les penseurs grecs avant Socrate. Paris: Garnier, 1964. p. 92-98.

ROUSSEAU, J.-J. Discurso sobre a origem e os fundamentos da desigualdade entre os homens. São Paulo: Martins Fontes, 1995.

VALLE, L. A escola imaginária. Rio de Janeiro: DP\&A, 1997.

VALLE, L. Teoria, determinação, complexidade: desafios da reflexão sobre educação. Trabalho, Educação \& Saúde, Rio de Janeiro, v. 1, n. 2, p. 185-201, 2003. 